\title{
In vitro evaluation of different chemical agents for the decontamination of gutta-percha cones
}

\section{Avaliação in vitro de diferentes agentes de descontaminação de cones de guta-percha}

\author{
Rogério Emílio de Souza* \\ Eduardo Antônio de Souza* \\ Manoel Damião Sousa-Neto** \\ Rosemeire Cristina Linhari Rodrigues Pietro***
}

\begin{abstract}
This study evaluated the effectiveness of three disinfectants used in Dentistry for decontamination of gutta-percha cones. Sixty gutta-percha cones were contaminated with standardized pure cultures of five species of microorganisms (Enterococcus faecalis ATCC 29212, Staphylococcus aureus ATCC 25923, Candida albicans ATCC CBS-ICB/USP 562, Bacillus subtilis spores ATCC 6633 and Streptococcus mutans ATCC 25175). The cones were treated with 10\% polyvinylpyrrolidone-iodine aqueous solution (PVP-I; Groups 1 and 2), 5.25\% aqueous sodium hypochlorite (Groups 3 and 4) and paraformaldehyde tablets (Group 5). All chemical agents were efficient for the cold sterilization of gutta-percha cones in short time periods.
\end{abstract}

DESCRIPTORS: Decontamination; Gutta-percha; Microbiology; Endodontics.

\begin{abstract}
RESUMO: A eficiência de três desinfetantes usados em Odontologia foi estudada na descontaminação de 60 cones de guta-percha contaminados com culturas puras e padronizadas de cinco cepas de microrganismos (Enterococcus faecalis ATCC 29212, Staphylococcus aureus ATCC 25923, Candida albicans ATCC CBS-ICB/USP 562, Bacillus subtilis em esporos ATCC 6633 e Streptococcus mutans ATCC 25175). Os cones foram tratados com solução aquosa de polivinilpirrolidona-iodo 10\% (PVP-I; Grupos 1 e 2), solução aquosa de hipoclorito de sódio 5,25\% (Grupos 3 e 4) e pastilhas de formaldeído (Grupo 5). Nossos resultados indicam que todos os agentes químicos foram eficientes para a esterilização a frio dos cones de guta-percha em curtos espaços de tempo.
\end{abstract}

DESCRITORES: Descontaminação; Guta-percha; Microbiologia; Endodontia.

\section{INTRODUCTION}

One of the primary objectives of root canal therapy is to eliminate or reduce microorganisms in the root canal. Decreasing the number of microorganisms without injuring adjacent vital tissues enhances endodontic success ${ }^{9}$. Considerable effort should be made to remove the existing microorganisms from the root canal and to prevent others from entering. During endodontic therapy, an aseptic sequence is one of the professional's main concerns $^{8}$ and must not be broken ${ }^{12}$.

Infectious microorganisms can be eradicated with biomechanical preparation ${ }^{13}$. However, in contrast with the care that is taken in cleansing the canals, gutta-percha cones are usually used directly from the package without regard to their sterility. Several studies tested the contamination of gutta-percha cones from unopened packages and show that all the cones tested were sterile ${ }^{3,6}$. However, Montgomery ${ }^{7}$ (1971) found that $8 \%$ of the tested cones were contaminated.

There is no consensus on the need for decontamination of the gutta-percha cones used to fill the root canal system. Nevertheless, the gutta-percha cones are not sterilized by standard autoclave or high temperature methods, because these procedures would cause deformation. Therefore, other methods of rapid decontamination of gutta-percha cones must be available in the clinic, such as paraformaldehyde, chlorhexidine, ethyl alcohol, polyvinylpyrrolidone-iodine, sodium hypochlorite, hydrogen peroxide, quaternary ammonium, and recently, electronic irradiation ${ }^{1}$. However, there is no agreement among authors on which of these methods is the best.

The aim of this investigation was to evaluate in vitro the antimicrobial effect of different chemical

*Graduate student, School of Dentistry; **PhD, Professor, School of Dentistry; ***PhD, Professor, Department of Pharmacology -

University of Ribeirão Preto. 
Souza RE de, Souza EA de, Sousa-Neto MD, Pietro RCLR. In vitro evaluation of different chemical agents for the decontamination of gutta-percha cones. Pesqui Odontol Bras 2003;17(1):75-7.

agents used for decontamination of gutta-percha cones contaminated with microorganisms. The chemical agents used were $10 \%$ polyvinylpyrrolidone-iodine solution with and without $96^{\circ} \mathrm{GL}$ alcohol, $5.25 \%$ sodium hypochlorite and paraformaldehyde tablets.

\section{MATERIAL AND METHODS}

Enterococcus faecalis ATCC 29212, Staphylococcus aureus ATCC 25923, Candida albicans ATCC CBS-ICB/USP 562, Bacillus subtilis spores ATCC 6633 and Streptococcus mutans ATCC 25175 were tested.

Pure microorganism culture strains were cultivated in test tubes containing $5 \mathrm{ml}$ of the broth BHI (Brain Heart Infusion), and incubated for $24 \mathrm{~h}$ at $37^{\circ} \mathrm{C}$ or in anaerobic jars in a $10 \% \mathrm{CO}_{2}$ atmosphere. After growth the concentration was agitated and regulated to $0.5 \mathrm{McF}$ arland scale $\left(1.5 \times 10^{8} \mathrm{CFU} / \mathrm{ml}\right)$.

This study used 12 no. 40 principal guttapercha cones $\left(\right.$ Tanari $^{\circledR}$, Tanariman Industrial Ltda., Manacapuru, AM, Brazil) for each bacterial strain. Two gutta-percha cones were transferred directly from the package into sterile medium (negative control Group). The 60 principal gutta-percha cones were divided into 5 groups of 12 cones each and transferred individually into 5 tubes containing $5 \mathrm{ml}$ of each bacterial suspension $\left(1.5 \times 10^{8} \mathrm{CFU} / \mathrm{ml}\right)$, for $1 \mathrm{~h}$. The positive control Group was formed by two gutta-percha cones transferred to sterile test tubes containing sterile $\mathrm{BHI}$ without the decontamination method.
The chemical gutta-percha cones decontamination agents were: $10 \%$ polyvinylpyrrolidone-iodine solution (PVP-I) (Bioflora Manipullarium, Ribeirão Preto, SP, Brazil), 5.25\% sodium hypochlorite (Bioflora Manipullarium, Ribeirão Preto, SP, Brazil) and $500 \mathrm{mg}$ paraformaldehyde tablets $\left(\right.$ Ricie $^{\circledR}$, Wirath Indústria e Comércio Ltda, São Paulo, SP, Brazil).

Five different decontamination methods were tested to disinfect the contaminated gutta-percha cones of each bacterial strain, with two samples in each group. After each decontamination method all the gutta-percha cones were transferred to sterile trial tubes containing sterile $\mathrm{BHI}$ and incubated at $37^{\circ} \mathrm{C}$ for $24 \mathrm{~h}$, or under a $10 \% \mathrm{CO}_{2}$ atmosphere in anaerobic jars. Growth, as indicated by turbidity, was then recorded.

Group 1: the contaminated gutta-percha cones were immersed for $3 \mathrm{~s}$ in 10\% PVP-I solution and for $3 \mathrm{~s}$ in $96^{\circ} \mathrm{GL}$ alcohol. Group 2: the guttapercha cones were placed for $3 \mathrm{~s}$ in $10 \%$ PVP-I solution. Group 3: the cones were kept for $45 \mathrm{~s}$ in $5.25 \%$ sodium hypochlorite. Group 4: the cones were kept for $15 \mathrm{~s}$ in $5.25 \%$ sodium hypochlorite. Group 5: the gutta-percha cones were placed in paraformaldehyde tablets for $1 \mathrm{~h}$. After these procedures, the gutta-percha cones were dried in sterile gauze and transferred immediately to sterile BHI medium.

\section{RESULTS}

Results show that all the chemical agents of decontamination of gutta-percha cones were efficient (Table 1).

TABLE 1 - Decontamination treatment of gutta-percha cones.

\begin{tabular}{|c|c|c|c|c|c|c|c|c|c|c|c|c|c|c|}
\hline \multirow{4}{*}{ Microorganisms } & \multicolumn{10}{|c|}{ Chemical agents of decontamination of gutta-percha cones } & \multirow{2}{*}{\multicolumn{2}{|c|}{$\begin{array}{l}\text { Positive } \\
\text { control }\end{array}$}} & & \\
\hline & & & & & & & & & & & & & \multicolumn{2}{|c|}{$\begin{array}{c}\text { Negative } \\
\text { control }\end{array}$} \\
\hline & \multicolumn{14}{|c|}{ Sample number } \\
\hline & 1 & 2 & 1 & 2 & 1 & 2 & 1 & 2 & 1 & 2 & 1 & 2 & 1 & 2 \\
\hline E. faecalis & - & - & - & - & - & - & - & - & - & - & + & + & - & - \\
\hline S. mutans & - & - & - & - & - & - & - & - & - & - & + & + & - & - \\
\hline C. albicans & - & - & - & - & - & - & - & - & - & - & + & + & - & - \\
\hline S. aureus & - & - & - & - & - & - & - & - & - & - & + & + & - & - \\
\hline B. subtilis & - & - & - & - & - & - & - & - & - & - & + & + & - & - \\
\hline $\begin{array}{l}\text { Package sealed } \\
\text { cones }\end{array}$ & & & & & & & & & & & & & - & - \\
\hline
\end{tabular}


Souza RE de, Souza EA de, Sousa-Neto MD, Pietro RCLR. In vitro evaluation of different chemical agents for the decontamination of gutta-percha cones. Pesqui Odontol Bras 2003;17(1):75-7.

\section{DISCUSSION}

Montgomery $^{7}(1971)$ suggested the use of $10 \%$ PVP-I for gutta-percha cone decontamination $(S$. epidermis, S. aureus, F. diffusum, B. fusiformis and peptostreptococci) after 10 and $30 \mathrm{~s}$ and 1 through 6 minutes. Cardoso et al. ${ }^{2}$ (2000) evaluated the effectiveness of $10 \%$ PVP-I for 1, 5, 10 and $15 \mathrm{~min}$ and observed that this agent was bactericidal after 1 to $5 \mathrm{~min}$ for $S$. aureus, E. coli, E. faecalis and $B$. subtilis spores decontamination. Our results showed that the 3 second treatment with $10 \%$ PVP-I (alone or associated to $96^{\circ} \mathrm{GL}$ alcohol) was efficient for gutta-percha cone disinfection. However, alcohol favors gutta-percha cone drying.

Senia ${ }^{11}$ et al. (1975) studied the effect of sodium hypochlorite on disinfection of gutta-percha cones and confirmed the efficiency in decontamination of 4.5, 5 and 5.25\% solutions. Cardoso et al. ${ }^{2}$ (2000) studied the efficiency of $1 \%$ sodium hypochlorite decontamination of gutta-percha cones and confirmed its efficiency in 1 to $5 \mathrm{~min}$. However, Gomes et al. ${ }^{4}$ (2001) observed that the $1 \%$ sodium hypochlorite was only efficient after $5 \mathrm{~min}$. In our study the $5.25 \%$ sodium hypochlorite showed effi- ciency in decontaminating gutta-percha cones in 45 and in $15 \mathrm{sec}$.

Senia et al. ${ }^{10}(1977)$ evaluated the antimicrobial action of formocresol vapors on gutta-percha cone disinfection and concluded that bactericidal and sporicidal effects occurred in $16 \mathrm{~h}$. Stabholz et al. ${ }^{14}$ (1987) observed that paraformaldehyde vapors were an effective method of decontaminating guttapercha cones from the bacterial strains tested after $24 \mathrm{~h}^{5,11}$. Our investigation evaluated and confirmed the antimicrobial effect of paraformaldehyde vapors in $1 \mathrm{~h}$. Higgins et al. ${ }^{5}(1986)$ observed that formaldehyde volatilizes quickly, as shown by the fact that no formaldehyde was detected on the cones $24 \mathrm{~h}$ after powder removal. If formaldehyde is present on the cone surface at the time it is inserted into the canal, it may be released via dentinal tubules or the apical foramen, with unknown side effects.

\section{CONCLUSIONS}

1. All gutta-percha cone chemical decontamination agents studied were efficient.

2. Gutta-percha cones may be stored in sterile conditions, in contact with paraformaldehyde vapors for $1 \mathrm{~h}$.

3. Although some cones from unopened packages were not contaminated, it is recommended that cold sterilization be used.

8. Moraes LCT, Olmedo AB. Análise das condições de assepsia dos cones de guta-percha. Rev Gaúcha Odontol 1971;19:116-7.

9. Seltzer S, Bender IB. Factors affecting successful repair after root canal therapy. J Am Dent Assoc 1963;67:651-62.

10. Senia ES, Marraro RV, Mitchell JL. Cold sterilization of gutta-percha cones with formocresol vapors. J Am Dent Assoc 1977; 94:887-90.

11. Senia ES, Marraro RV, Mitchell JL, Lewis AG, Thomas L. Rapid sterilization of gutta-percha cones with $5.25 \%$ sodium hypochlorite. J Endod 1975;1:136-40.

12. Silva AS, Shimizu MT, Antoniazzi JH. Ação antimicrobiana de cones de guta-percha previamente contaminados. Rev Odontol Univ São Paulo 1994;8:33-6.

13. Siqueira JF Jr, Rjcas IN, Santos SR, Lima KC, Magalhães FA, Uzeda M. Efficacy of instrumentation techniques and irrigation regimens in reducing the bacterial population within root canals. J Endod 2002;28:181-4

14. Stabholz A, Stabholz A, Friedman S, Heling I, Sela MN. Efficiency of different chemical agents in decontamination of gutta-percha cones. Int Endod J 1987;20:211-6. 
Souza RE de, Souza EA de, Sousa-Neto MD, Pietro RCLR. In vitro evaluation of different chemical agents for the decontamination of gutta-percha cones. Pesqui Odontol Bras 2003;17(1):75-7.

Recebido para publicação em $12 / 08 / 02$ Enviado para reformulação em 12/02/03 Aceito para publicação em $28 / 02 / 03$ 